\title{
Alimentación Saludable para Personas de Edad: Dieciséis Comidas Saludables Para "Picar"1
}

\section{Jennifer Hillan ${ }^{2}$}

Aquí les presentamos algunas ideas para "picar" que además de fáciles son saludables. Use estas ideas la próxima vez que se sienta con ganas de "picar" algo.

1. Tiras de calabacín con salsa ranch baja en grasa o yogur natural

2. Banana helada (pele la banana antes de congelarla)

3. $1 / 2$ bagel con mermelada

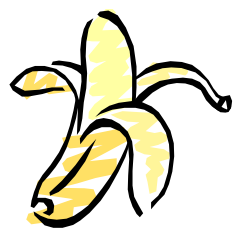

4. $1 / 4$ taza de fruta seca variada

5. Galletas del tipo Graham con crema de maní

6. 1 taza de leche agria (buttermilk)

7. $1 \frac{1}{2}$ onzas de tiras de queso bajo en grasa

8. Helados caseros (hechos con jugo de frutas o vegetales)
9. 1 taza de yogur descremado

10. 1 huevo cocido con $3 / 4$ taza de jugo de frutas

11. $1 / 2$ taza de pepino en rodajas $y$ tomates con salsa baja en grasa tipo Italian o yogur natural

12. Pan tipo pita con hummus (salsa de garbanzos machacados)

13. Rebanada de pan integral tostado con margarina y un pizca de azúcar y canela

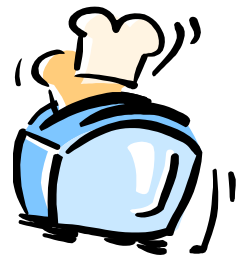

14. Tortilla con queso fundido

15. $1 / 2$ taza de melón cortado en cubitos

16. $3 / 4$ taza de jugo de vegetales bajo en sodio con 3-4 galletas saladas integrales

1. This is document FCS 8697-SPAN, one in a series of the Department of Family, Youth and Community Sciences, Florida Cooperative Extension Service, Institute of Food and Agricultural Sciences, University of Florida, Gainesville, FL 32611. Publication date: February 2005. The English version of this Spanish language leaflet is Healthy Eating for Elders: Sixteen Savory Snacks. This leaflet was developed with funding from the Florida Department of Elder Affairs in partnership with state, county, and local agencies. Please visit the EDIS Web site at http://edis.ifas.ufl.edu

2. Jennifer Hillan, MSH, RD, LD/N, former ENAFS nutrition educator/trainer, Department of Family, Youth and Community Sciences, Institute of Food and Agricultural Sciences, University of Florida, Gainesville, FL 32611. English version reviewed by Linda B. Bobroff, PhD, RD, LD/N, professor, and Leigh Ann Martin, MESS, former ENAFS project coordinator, University of Florida. Translated by Sergio Romero, MS, ATC, University of Florida. Translation reviewed by Isabel Valentín-Oquendo, MS, $\mathrm{RD}$, former curriculum coordinator FNP, University of Florida. 